\title{
Soil carbon mineralization following biochar addition associated with external nitrogen
}

\author{
Rudong Zhao' ${ }^{1}$ Neil Coles ${ }^{2}$, and Jiaping $\mathrm{Wu}^{1 *}$
}

Biochar has been attracting increasing attention for its potentials of $\mathrm{C}$ sequestration and soil amendment. This study aimed to understand the effects of combining biochar with additional external $\mathrm{N}$ on soil $\mathrm{C}$ mineralization. A typical red soil (Plinthudults) was treated with two biochars made from two types of plantation-tree trunks (soil-biochar treatments), and was also treated with external $\mathrm{N}$ (soil-biochar- $\mathrm{N}$ treatments). All treatments were incubated for $42 \mathrm{~d}$. $\mathrm{The}_{\mathrm{CO}}-\mathrm{C}$ released from the treatments was detected periodically. After the incubation, soil properties such as $\mathrm{pH}$, microbial biomass $\mathrm{C}$ (MBC), and microbial biomass $\mathrm{N}(\mathrm{MBN})$ were measured. The addition of biochar with external $\mathrm{N}$ increased the soil $\mathrm{pH}(4.31-4.33)$ compared to the soil treated with external $\mathrm{N}$ only (4.21). This was not observed in the comparison of soil-biochar treatments (4.75-4.80) to soil only (4.74). Biochar additions (whether or not they were associated with external N) increased soil MBC and $\mathrm{MBN}$, but decreased $\mathrm{CO}_{2}-\mathrm{C}$ value per unit total $\mathrm{C}$ (added biochar $\mathrm{C}+$ soil $\mathrm{C}$ ) according to the model fitting. The total $\mathrm{CO}_{2}-\mathrm{C}$ released in soil-biochar treatments were enhanced compared to soil only (i.e., 3.15 vs. $2.57 \mathrm{mg}$ and 3.23 vs. 2.45 $\mathrm{mg}$ ), which was attributed to the labile $\mathrm{C}$ fractions in the biochars and through soil microorganism enhancement. However, there were few changes in soil $\mathrm{C}$ mineralization in soil-biochar- $\mathrm{N}$ treatments. Additionally, the potentially available $\mathrm{C}$ per unit total $\mathrm{C}$ in soil-biochar- $\mathrm{N}$ treatments was lower than that observed in the soil-biochar treatments. Therefore, we believe in the short term, that $\mathrm{C}$ mineralization in the soil can be enhanced by biochar addition, but not by adding external $\mathrm{N}$ concomitantly.

Key words: Biochar, carbon sequestration, nitrogen, soil amendment.

\section{INTRODUCTION}

Biochar incorporation into soils can potentially sequester C and amend soils (Yu et al., 2010; Mulcahy et al., 2013; Spokas, 2013; Zhang et al., 2014). However, soil C mineralization can be altered by biochar within a short time, and the mechanism underlying this process warrants further investigation (Verheijen et al., 2014). A small fraction of labile $\mathrm{C}$ in biochar can be mineralized within a short period (Kuzyakov et al., 2009) and can stimulate soil microorganism growth (Quilliam et al., 2013). Biochar can provide a substrate for soil microorganisms, thereby enhancing microorganism activity (Gomez et al., 2014). This microbial growth induces soil $\mathrm{C}$ mineralization or degradation (Smith et al., 2010; Luo et al., 2011). However, other studies indicate that biochar alters the soil microbial community structure rather than biomass

\footnotetext{
${ }^{1}$ Zhejiang University, Institute of Islands and Coastal Ecosystems, Hangzhou 310058, China.

*Corresponding author (jw67@zju.edu.cn; zhrd255@126.com).

${ }^{2}$ The University of Western Australia, Institute of Agriculture, Crawley, WA 6009, Australia.

Received: 20 January 2015.

Accepted: 17 July 2015.

doi:10.4067/S0718-58392015000500012
}

(Anders et al., 2013) and suppresses soil C mineralization through its adsorptive and biochemical effects (Jones et al., 2011). This variation in behavior and activity requires further clarification. An additional benefit of biochar is the potential to ameliorate soil acidification through the breakdown of carbonates contained in biochar (Bruun et al., 2014).

Nitrogen fertilizer application associated with biochar improves $\mathrm{N}$ utilization efficiency through mineral retention and biological fixation, and has the potential to increase N uptake by crops (Borchard et al., 2012). Thus, C sequestration and soil amendment can be simultaneously achieved by using biochar with $\mathrm{N}$ fertilizer. However, few studies have described soil $\mathrm{C}$ mineralization kinetics following biochar addition with external $\mathrm{N}$, which is important for biochar $\mathrm{C}$ sequestration. External $\mathrm{N}$ addition can enhance soil microorganism growth, which may promote organic $\mathrm{C}$ degradation in soils (Gundale and DeLuca, 2007). Abiotic C mineralization dominates $\mathrm{C}$ mineralization process in a relatively short time (e.g., weeks to months) after biochar addition to soils (Cheng et al., 2006). However, this process may be modified when external $\mathrm{N}$ is combined with biochar as the additional $\mathrm{N}$ can affect soil microorganisms (Kolb et al., 2009), improving the soil microbial biomass $\mathrm{C}$ when compared to biochar alone (Chan et al., 2008). In another study, this 
association results in a decrease in soil $\mathrm{pH}$ over a period of $55 \mathrm{~d}$ (Clough et al., 2010), which may cause a decrease in soil microorganism activities (Aciego Pietri and Brookes, 2008). Therefore, combination of biochar with external $\mathrm{N}$ does not always promote soil $\mathrm{C}$ mineralization, as evidenced by the limited effect of biochar when combined with dairy manure on soil $\mathrm{CO}_{2}$ release, relative to biochar alone (Sarkhot et al., 2012). Elucidation of soil $\mathrm{C}$ mineralization after biochar addition with external $\mathrm{N}$ is necessary not only for understanding soil organic $\mathrm{C}$ kinetics and soil amendment performance, but also for determining the effectiveness of $\mathrm{C}$ sequestration.

Laboratory incubation with standardized conditions is an effective method to examine $\mathrm{C}$ mineralization (Lefèvre et al., 2014). First-order models can be used to describe $\mathrm{C}$ mineralization kinetics after the addition of external materials (e.g., biochar) (Zhou et al., 2012; Quilliam et al., 2013). Plantation wastes of Pinus massoniana Lamb. and Cunninghamia lanceolata (Lamb.) Hook. are widely distributed in southern China; such wastes could be pyrolyzed to promote $\mathrm{C}$ sequestration and soil amendment. This study investigated $\mathrm{C}$ mineralization in a typical acidic soil of southern China, after adding biochar and external $\mathrm{N}$. We hypothesized that plantation-waste biochar when combined with external $\mathrm{N}$ could amend acidic soils and enhance on soil $\mathrm{C}$ mineralization more effectively than biochar alone.

\section{MATERIALS AND METHODS}

\section{Sample collection}

Topsoil samples $(0-30 \mathrm{~cm})$ from a typical quaternary red soil (Plinthudults) were collected in Zhejiang Province $\left(27^{\circ} 02^{\prime}-31^{\circ} 11^{\prime} \mathrm{N}, 118^{\circ} 01^{\prime}-123^{\circ} 25^{\prime} \mathrm{E}\right)$. The average annual temperature range is $15-19^{\circ} \mathrm{C}$ and the mean annual precipitation is $1300 \mathrm{~mm}$. The $\mathrm{pH}(1: 2.5 \mathrm{w} / \mathrm{v})$, organic C content and total $\mathrm{N}$ content of the soil sample were 4.84 , $4.20 \mathrm{~g} \mathrm{~kg}^{-1}$, and $0.28 \mathrm{~g} \mathrm{~kg}^{-1}$, respectively. The proportions of sand $(2.00-0.05 \mathrm{~mm})$, silt $(0.05-0.002 \mathrm{~mm})$, and clay $(<0.002 \mathrm{~mm})$ in soil samples were $21.67 \%, 37.00 \%$, and $41.33 \%$, respectively. Freshly cut $P$. massoniana and $C$. lanceolata trunks were collected as biochar feedstock.

\section{Biochar preparation}

The trunk samples were air-dried and shattered to provide 1-2 $\mathrm{cm}^{3}$ pieces, which were then placed in covered crucibles. The samples were pyrolyzed in a programmed muffle furnace (Shanghai Jinghong Laboratory Equipment Inc., Shanghai, China). A maximum temperature of 450 ${ }^{\circ} \mathrm{C}$ was selected as it was close to the temperature of natural forest fire (Wolf et al., 2013). The temperature

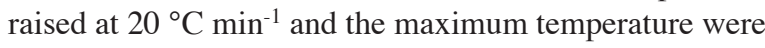
maintained for $1 \mathrm{~h}$. Biochars made from P. massoniana and $C$. lanceolata trunks were ready (labeled as PB and $\mathrm{CB}$, respectively) when the furnace cooled to room temperature without disturbance. After being passed through a $1 \mathrm{~mm}$ sieve, the biochar samples were sealed in brown jars and stored in the dark.

\section{Biochar characteristic analysis}

Each biochar sample was mixed with deionized water $(1: 5 \mathrm{w} / \mathrm{v})$ and then stirred with an electromagnetic stirrer for $2 \mathrm{~min}$. After equilibrating for $1 \mathrm{~h}$, the $\mathrm{pH}$ was determined with a digital pH meter (Sanxin-MP521, Shanghai Youyi Co., Shanghai, China). Volatile matter content was determined by measuring the difference in weight loss with the combustion of the biochar sample in a ceramic crucible at $950{ }^{\circ} \mathrm{C}$ for $6 \mathrm{~min}$, and the ash content was determined by placing the sample at $750{ }^{\circ} \mathrm{C}$ for $6 \mathrm{~h}$ in a programmed muffle furnace (ASTM, 2007). The concentrations of elemental $\mathrm{C}, \mathrm{H}$, and $\mathrm{N}$ in the biochar sample were analyzed with an elements analyzer (Flash EA 1112, Thermo Finnigan, Milan, Italy). The O concentration was calculated using the weight difference, assuming that the biochars consisted of $\mathrm{C}, \mathrm{H}, \mathrm{N}$, and $\mathrm{O}$ only. The results were determined using the ash-free dry weight. The carbonate content was measured using a volumetric analysis method as described in the literature (Yuan et al., 2011).

The Brunauer-Emmet-Teller (BET) surface area was measured using the $\mathrm{N}$ gas adsorption-desorption method on an Autosorb-1-C analyzer (Quantachrome Instruments, Boynton Beach, Florida, USA). Each biochar sample was analyzed for approximately $5 \mathrm{~h}$ after being degassed at $300{ }^{\circ} \mathrm{C}$, with the total time dependent on the time taken to reach stabilization. The surface area was calculated with a multipoint plot over a $\mathrm{P} / \mathrm{Po}$ range of $0.05-0.35$. Fourier-transform infra red (FTIR) methodology was employed to detect any surface functional groups on a Nicolet 5700 (Nicolet Instrument, Thermo Electron Corporation, Madison, Wisconsin, USA). The biochar sample was initially mixed with potassium bromide $(\mathrm{KBr})$ at the ratio of approximate $1 \%$, and then this mixture was milled using an agate mortar and pressed into a pellet. The FTIR spectrum was normalized to the highest peaks in the fingerprint (4000-400 $\left.\mathrm{cm}^{-1}\right)$ with a resolution of $4.0 \mathrm{~cm}^{-1}$.

The dissolved organic $\mathrm{C}$ (DOC), total soluble $\mathrm{N}$ (TSN), nitrate $\mathrm{N}$, and ammonium $\mathrm{N}$ in the biochar were analyzed according to Gaskin et al. (2008). One gram biochar sample (0.3 mm sieve) was mixed with $20 \mathrm{~mL}$ of deionized water in a disposable cellulose nitrile filter $(0.45 \mu \mathrm{m})$ flask. The flask was shaken for $5 \mathrm{~min}(180 \mathrm{rpm})$ and then vacuum filtered. The leachate was collected after this process which was replicated five times to measure DOC and TSN using a multi N/C 3100 analyzer (Analytik Jena AG, Jena, Germany), and to measure nitrate $\mathrm{N}$ and ammonium $\mathrm{N}$ using a flow injection analyzer (SA-4000, Skalar Co., Breda, The Netherlands).

\section{Incubation experiment}

Twenty gram soil samples (dw; $2 \mathrm{~mm}$ sieve) were treated with $\mathrm{N}\left(\mathrm{NH}_{4} \mathrm{NO}_{3}\right)$ and the biochar samples. The 
$\mathrm{N}$ addition rate of $0.15 \mathrm{~N} \mathrm{~g} \mathrm{~kg}^{-1}$ was selected based on local agricultural practices (Ye et al., 2012). Soil-biochar treatments consisted of soil $+1 \%$ PB (SP1), soil $+1 \%$ $\mathrm{CB}$ (SC1), soil + 2\% PB (SP2), and soil + 2\% CB (SC2). Soil-biochar-N treatments consisted of soil $+1 \% \mathrm{~PB}+$ $\mathrm{N}(\mathrm{SP} 1 \mathrm{~N})$, soil $+1 \% \mathrm{CB}+\mathrm{N}(\mathrm{SC} 1 \mathrm{~N})$, soil $+2 \% \mathrm{~PB}+\mathrm{N}$ $(\mathrm{SP} 2 \mathrm{~N})$, and soil $+2 \% \mathrm{CB}+\mathrm{N}(\mathrm{SC} 2 \mathrm{~N})$. Both the PB and $\mathrm{CB}$ samples were mixed with quartz sand (at $2 \%$ based on SP2 or SC2) which had been washed with $1 \mathrm{M} \mathrm{HCl}$ and then distilled water to a neutral $\mathrm{pH}$ (i.e., sand-biochar treatments; labeled as QP2 and QC2, respectively). Treatments of soil $+\mathrm{N}(\mathrm{SN})$ and soil only (CK) were set as controls. All treatments were replicated three times.

Soil treatments were adjusted to $40 \%$ water-holding capacity (WHC), and all treatments were placed into $1 \mathrm{~L}$ Erlenmeyer flasks. A tube containing $5 \mathrm{~mL} \mathrm{NaOH}(0.10$ $\mathrm{M})$ solution was placed into each flask to trap $\mathrm{CO}_{2}$. The flask was sealed with a rubber stopper and incubated at $25{ }^{\circ} \mathrm{C}$ in the dark. The $\mathrm{CO}_{2}$ captured by the $\mathrm{NaOH}$ solution was titrated with $0.1 \mathrm{M} \mathrm{HCl}$ solution at $1,2,4$, $8,12,15,22,32$, and $42 \mathrm{~d}$ incubation periods. The results were calculated as $\mathrm{C}$ contents in $\mathrm{CO}_{2}\left(\mathrm{CO}_{2}-\mathrm{C}\right)$. At each titration, each flask was ventilated for $2 \mathrm{~min}$ and a new tube containing fresh $\mathrm{NaOH}$ solution replaced the old one. During the incubation, the moisture in the soil treatments was maintained at $40 \%$ WHC by weekly weighing and adding distilled water.

\section{Soil properties analysis after incubation}

Each soil sample was air-dried and mixed with deionized water $(1: 2.5$ by $w / v)$. The mixture was stirred with a magnetic stirrer for 1-2 $\mathrm{min}$, and equilibrated for 30 min. The $\mathrm{pH}$ was measured with a digital $\mathrm{pH}$ meter. Five grams of moist soil sample were mixed with $25 \mathrm{~mL}$ ultra-pure water and shaken for $90 \mathrm{~min}(180 \mathrm{rpm})$. After being centrifuged for $15 \mathrm{~min}$ (4000 rpm), the mixture was filtered through a $0.45 \mu \mathrm{m}$ millipore filter. The extract was measured for DOC and DON on a multi N/C 3100 analyzer. The moist soil sample was mixed with $2 \mathrm{~mol}$ $\mathrm{L}^{-1} \mathrm{KCl}(1: 5$ by w/v) and shaken for $1 \mathrm{~h}(180 \mathrm{rpm})$ then filtered. The extract was measured for nitrate $\mathrm{N}$ and ammonium $\mathrm{N}$ using a flow injection analyzer.

The moist soil sample (equivalent to $10 \mathrm{~g} \mathrm{dw}$ ) was fumigated with alcohol-free chloroform for $24 \mathrm{~h}$ at 25 ${ }^{\circ} \mathrm{C}$, then extracted with $40 \mathrm{~mL} \mathrm{~K}_{2} \mathrm{SO}_{4}$ solution for $30 \mathrm{~min}$ $(180 \mathrm{rpm})$ and filtered. The corresponding unfumigated soil sample was treated in the same way. Both extracts from fumigated and unfumigated samples were tested for soluble organic $\mathrm{C}$ and total $\mathrm{N}$ using a multi $\mathrm{N} / \mathrm{C}$ 3100 analyzer. The soil microbial biomass $\mathrm{C}$ (MBC) was estimated by the difference (EC) between the organic $\mathrm{C}$ extracted from fumigated and unfumigated samples according to Equation [1] (Vance et al., 1987). Soil microbial biomass N (MBN) was estimated by the difference (EN) between the soluble total $\mathrm{N}$ extracted from fumigated and unfumigated samples according to
Equation [2] (Brookes et al., 1985):

$$
\begin{aligned}
& M B C=E C \times 2.64 \\
& M B N=E N \times 1.85
\end{aligned}
$$

where, 2.64 and 1.85 in the equations are dimensionless constants.

\section{Statistics}

The data among different treatments was compared using the one-way ANOVA with the Tukey's significant $(\mathrm{P}<0.05)$ difference as a post hoc test using SPSS v18.0 (SPSS Inc., Chicago, Illinois, USA). A bivariate correlation (Pearson, two-tailed) was applied to determine the correlation between $\mathrm{pH}$ and total cumulative $\mathrm{CO}_{2}$-C. A first-order kinetic model was employed to fit cumulative $\mathrm{CO}_{2}-\mathrm{C}$ evolution using Origin 8.5 (OriginLab Corp., Northampton, Massachusetts, USA). The first-order model is given in Equation [3]:

$$
C_{\mathrm{t}}=C_{0}\left(1-\mathrm{e}^{-k t}\right)
$$

where, $C_{\mathrm{t}}$ is mineralized $\mathrm{C}$ at time $\mathrm{t}$; $C_{0}$ is the potentially available $\mathrm{C}$ (labile $\mathrm{C}$ potential); $k$ is apparent rate constant; and $t$ is time of incubation (Zhou et al., 2012).

\section{RESULTS}

The PB and CB had similar elemental concentrations $(\mathrm{C}$, $\mathrm{H}, \mathrm{N}$, and $\mathrm{O}$ ), DOC, nitrate $\mathrm{N}, \mathrm{pH}$, volatile matter, and ash (Table 1). Biochar CB had higher amounts of TSN and ammonium $\mathrm{N}$ than $\mathrm{PB}$, while $\mathrm{PB}$ had larger surface areas. Carbonates were not detected in either of the biochar samples. Similar functional groups were observed on both PB and CB (Figure 1). Peaks at around $3385 \mathrm{~cm}^{-1}$ were assigned to hydroxyl structures, while peaks at around 1195,880 , and $758 \mathrm{~cm}^{-1}$ were assigned to aromatic structures. Peaks at 1705 and $1600 \mathrm{~cm}^{-1}$ were attributed to carbonyl and carboxyl structures, respectively.

Biochar additions increased cumulative $\mathrm{CO}_{2}-\mathrm{C}$ release (Figure 2 and Table 2). Soil-biochar treatments had higher levels of cumulative $\mathrm{CO}_{2}$-C evolution than soil-biochar- $\mathrm{N}$

Table 1. Characteristics of biochars made from Pinus massoniana trunk (PB) and made from Cunninghamia lanceolata trunk (CB).

\begin{tabular}{lrr}
\hline & \multicolumn{2}{c}{ Biochars } \\
\cline { 2 - 3 } Items & \multicolumn{1}{c}{$\mathrm{PB}$} & $\mathrm{CB}$ \\
\hline Element C, mg kg-1 & 704.60 & 712.10 \\
Element H, mg kg-1 & 23.90 & 24.70 \\
Element N, mg kg-1 & 1.30 & 3.20 \\
Element O, mg kg-1 & 270.20 & 260.00 \\
$\mathrm{O}: \mathrm{C}$ & 0.38 & 0.37 \\
$\mathrm{H}: \mathrm{C}\left(\times 10^{-2}\right)$ & 3.39 & 3.47 \\
DOC, $\mathrm{g} \mathrm{kg}^{-1}$ & 2.54 & 1.88 \\
TSN, mg kg-1 & 27.23 & 45.92 \\
Nitrate N, mg kg-1 & 3.54 & 2.60 \\
Ammonium N, mg kg-1 & 10.76 & 22.18 \\
pH & 5.01 & 4.88 \\
Volatile matter, mg kg-1 & 10.10 & 9.70 \\
Ash, mg kg & 14.00 & 10.30 \\
Carbonates, mg kg-1 & $\mathrm{ND}$ & $\mathrm{ND}$ \\
BET surface area, m${ }^{-1} \mathrm{~g}^{-1}$ & 224.30 & 145.50 \\
\hline
\end{tabular}

DOC: Dissolved organic C; TSN: total soluble N, BET: Brunauer-EmmetTeller, ND: not detected. 


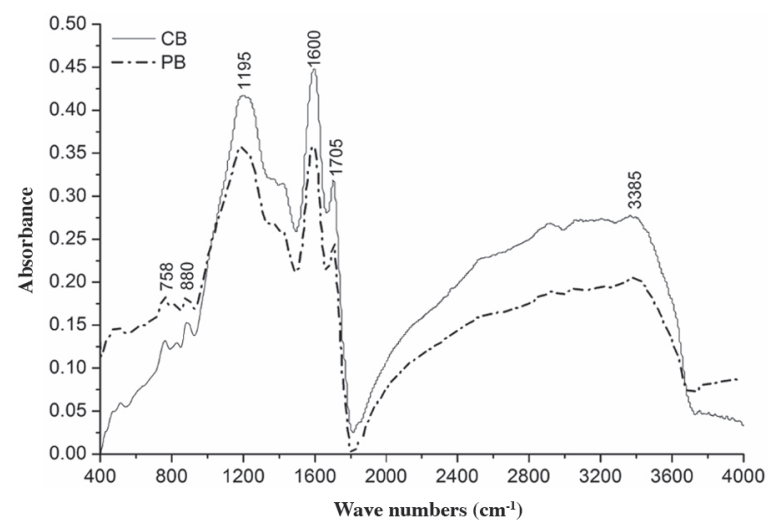

Figure 1. Fourier-transform infrared (FTIR) spectra for biochars made from Pinus massoniana trunk (PB) and made from Cunninghamia lanceolata trunk (CB).

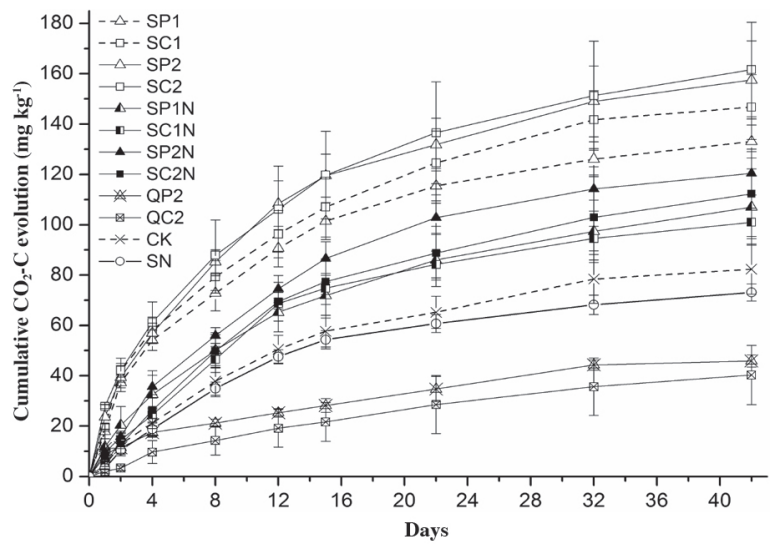

SP1: soil $+1 \%$ biochar made from Pinus massoniana trunk (PB); $\mathrm{SC} 1$ : soil $+1 \%$ biochar made from Cunninghamia lanceolata trunk (CB); SP2: soil $+2 \%$ PB; SC2: soil $+2 \%$ CB; SP1N: soil $+1 \%$ PB + N; SC1N: soil $+1 \%$ CB + N; SP2N: soil + $2 \%$ PB + N; SC2N: soil + $2 \%$ CB + N; QP2: quartz sand + PB; QC2: quartz sand + CB; CK: soil only; SN: soil + N.

Figure 2. Measured cumulative $\mathrm{CO}_{2}-\mathrm{C}$ evolutions during $42 \mathrm{~d}$ (error bars are \pm standard deviation, $n=3$ ).

treatments. The measured cumulative $\mathrm{CO}_{2}-\mathrm{C}$ values were normalized to total $\mathrm{C}$ (added biochar $\mathrm{C}+$ native soil $\mathrm{C}$ ), which were then fitted using first-order kinetic models (Figure 3). The kinetic model adequately described the degree of conformity between the experimentation data and the model-predication as indicated by the $R^{2}$ coefficients (Table 2). Whether or not associated with external $\mathrm{N}$, the biochar additions did decrease the cumulative $\mathrm{CO}_{2}-\mathrm{C}$ evolution per unit total $\mathrm{C}$ (Figure 3 and Table 2). According to the first-order model, the biochar additions, and in particular the $2 \%$-additions decreased the labile $\mathrm{C}$ potential per unit total $\mathrm{C}\left(C_{0}\right)$. The rate constant $(k)$ values were higher in the soil-biochar treatments than in the other treatments. Soil-biochar and soil-biochar-N mixtures had lower mineralizable $\mathrm{C}$ potential per unit total $\mathrm{C}\left(C_{1}+C_{2}\right)$ than $\mathrm{CK}$ and $\mathrm{SN}$.

Small changes in soil DOC and DON after biochar addition alone were observed (Table 3). Soil-biochar-N treatments demonstrated higher levels of nitrate $\mathrm{N}$ and
Table 2. Total values of cumulative $\mathrm{CO}_{2}-\mathrm{C}$ and estimated parameters according to first-order model.

\begin{tabular}{|c|c|c|c|c|c|}
\hline \multirow[b]{2}{*}{ Treatments } & \multirow{2}{*}{$\begin{array}{c}\text { Total } \\
\text { cumulative } \\
\mathrm{CO}_{2}-\mathrm{C} \\
\text { values }\end{array}$} & \multirow{2}{*}{$\begin{array}{c}\text { Total } \\
\text { cumulative } \\
\mathrm{CO}_{2}-\mathrm{C} \text { per unit } \\
\text { total } \mathrm{C} \text { (added } \mathrm{C} \\
+ \text { soil } \mathrm{C} \text { ) }\end{array}$} & \multicolumn{3}{|c|}{ First-order model } \\
\hline & & & $\mathrm{R}^{2}$ & $C_{0}$ & $\mathrm{k}\left(10^{-2}\right)$ \\
\hline & $\mathrm{mg} \mathrm{kg}^{-1}$ & $\mathrm{mg} \mathrm{g}^{-1}$ & & & \\
\hline SP1 & $133.09 \pm 6.54 \mathrm{cde}$ & $11.83 \pm 0.58 \mathrm{~d}$ & 0.983 & 11.45 & 11.30 \\
\hline $\mathrm{SC} 1$ & $146.77 \pm 12.90 \mathrm{e}$ & $12.96 \pm 1.14 \mathrm{~d}$ & 0.977 & 12.65 & 10.50 \\
\hline SP2 & $157.52 \pm 15.48 \mathrm{e}$ & $8.61 \pm 0.8$ & 0.988 & 8.37 & 10.60 \\
\hline $\mathrm{SC} 2$ & $161.65 \pm 18.79 \mathrm{e}$ & $8.77 \pm 1.02 \mathrm{bc}$ & 0.980 & 8.45 & 10.70 \\
\hline SP1N & $107.03 \pm 15.15 b c$ & $9.52 \pm 1.35 \mathrm{c}$ & 0.993 & 9.55 & 7.87 \\
\hline $\mathrm{SC} 1 \mathrm{~N}$ & $100.99 \pm 5.61 b c$ & $8.92 \pm 0.5$ & 0.994 & 9.22 & 7.86 \\
\hline SP2N & $120.47 \pm 8.61 \mathrm{~cd}$ & $6.59 \pm 0.47 \mathrm{bc}$ & 0.999 & 6.86 & 7.64 \\
\hline $\mathrm{SC} 2 \mathrm{~N}$ & $112.29 \pm 17.81 \mathrm{bcd}$ & $6.09 \pm 0.97 b$ & 0.997 & 6.35 & 6.93 \\
\hline QP2 & $45.89 \pm 2.40 \mathrm{a}$ & $3.26 \pm 0.17 \mathrm{a}$ & 0.919 & 3.27 & 7.69 \\
\hline QC2 & $40.29 \pm 11.76 \mathrm{a}$ & $2.83 \pm 0.83 a$ & 0.995 & 3.37 & 4.24 \\
\hline CK & $82.39 \pm 9.98 b$ & $19.62 \pm 2.38 \mathrm{e}$ & 0.998 & 20.52 & 7.17 \\
\hline SN & $73.08 \pm 3.40 \mathrm{~b}$ & $17.40 \pm 0.81 \mathrm{e}$ & 0.997 & 17.9 & 7.92 \\
\hline
\end{tabular}

SP1: Soil + $1 \%$ biochar made from Pinus massoniana trunk (PB); SC1: soil + $1 \%$ biochar made from Cunninghamia lanceolata trunk (CB); SP2: soil $+2 \%$ PB; SC2: soil + $2 \%$ CB; SP1N: soil + 1\% PB + N; SC1N: soil + $1 \%$ CB + N; SP2N: soil + $2 \% \mathrm{~PB}+\mathrm{N}$; SC2N: soil $+2 \% \mathrm{CB}+\mathrm{N}$; QP2: quartz sand $+\mathrm{PB}$ QC2: quartz sand $+\mathrm{CB}$; CK: soil only; $\mathrm{SN}$ : soil $+\mathrm{N}$.

Values are mean \pm standard deviation $(n=3)$. Those values followed by the same letters in each volume are not significantly different (ANOVA, Tukey's test, $P<0.05)$

$R^{2}$ : correlation coefficient; $C_{0}$ : the potentially available C (labile C potential); $k$ : apparent rate constant.

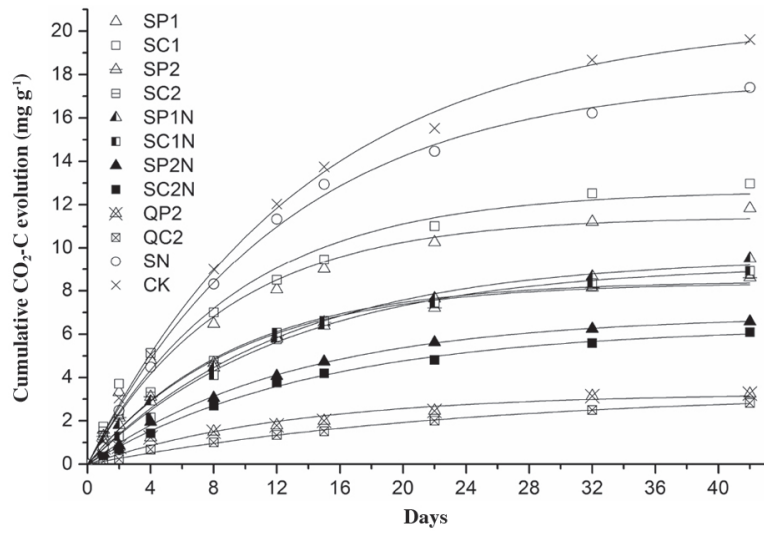

Figure 3. Cumulative $\mathrm{CO}_{2}$-C evolutions per unit total $\mathrm{C}$ (added biochar $\mathrm{C}+$ soil $\mathrm{C}$ ) according to first-order model.

ammonium $\mathrm{N}$ than $\mathrm{SN}$, but the differences were not observed in the comparison of soil-biochar treatments to $\mathrm{CK}$. The soil amended with biochar and external $\mathrm{N}$ improved the soil $\mathrm{MBC}$ and $\mathrm{MBN}$ contents. Soil $\mathrm{pH}$ values could be ranked as: soil-biochar treatments $=\mathrm{CK}>$ soil-biochar-N treatments $>\mathrm{SN}$.

\section{DISCUSSION}

\section{Effects of biochar addition on soil $\mathbf{C}$ mineralization}

No change was observed in the soil DOC after biochar additions, which is similar to previous findings (Jones et al., 2012). The $\mathrm{CO}_{2}-\mathrm{C}$ evolution distribution and higher levels of total $\mathrm{CO}_{2}-\mathrm{C}$ released in SP2 vs. QP2 $+\mathrm{CK}$ and SC2 vs. QC2 + CK (Table 4) suggest that soil $\mathrm{C}$ mineralization can be enhanced by the biochar additions, which is consistent with the previous report 
Table 3. Soil properties after incubation.

\begin{tabular}{|c|c|c|c|c|c|c|c|}
\hline Treatments & DOC & $\mathrm{DON}$ & $\mathrm{MBC}$ & MBN & Nitrate $\mathrm{N}$ & Ammonium $\mathrm{N}$ & $\mathrm{pH}$ \\
\hline & & & mg k & & & & \\
\hline SP1 & $177.61 \pm 15.25 a$ & $4.56 \pm 0.67 \mathrm{a}$ & $40.05 \pm 1.97 b$ & $8.20 \pm 0.82 b$ & $6.56 \pm 0.90 \mathrm{a}$ & $5.08 \pm 0.77 \mathrm{a}$ & $4.80 \pm 0.02 c$ \\
\hline $\mathrm{SC} 1$ & $197.83 \pm 21.45 \mathrm{ab}$ & $4.79 \pm 0.11 \mathrm{a}$ & $38.80 \pm 7.25 b$ & $7.80 \pm 2.27 \mathrm{ab}$ & $6.37 \pm 1.14 \mathrm{a}$ & $5.95 \pm 0.64 a$ & $4.77 \pm 0.01 \mathrm{c}$ \\
\hline SP2 & $182.34 \pm 24.35 \mathrm{ab}$ & $4.00 \pm 0.47 \mathrm{a}$ & $44.15 \pm 10.14 b$ & $8.01 \pm 2.21 \mathrm{ab}$ & $5.62 \pm 0.72 \mathrm{a}$ & $4.53 \pm 0.79 a$ & $4.79 \pm 0.01 \mathrm{c}$ \\
\hline $\mathrm{SC} 2$ & $219.36 \pm 25.35 \mathrm{ab}$ & $4.21 \pm 0.28 \mathrm{a}$ & $39.06 \pm 5.70 b$ & $8.83 \pm 1.55 b$ & $6.18 \pm 0.83 a$ & $4.70 \pm 0.82 \mathrm{a}$ & $4.75 \pm 0.01 \mathrm{c}$ \\
\hline SP1N & $201.52 \pm 16.35 \mathrm{ab}$ & $191.34 \pm 6.36 b$ & $38.63 \pm 7.92 b$ & $8.59 \pm 2.26 a b$ & $86.99 \pm 1.11 \mathrm{c}$ & $82.34 \pm 0.57 c$ & $4.33 \pm 0.03 b$ \\
\hline $\mathrm{SC} 1 \mathrm{~N}$ & $213.51 \pm 14.71 \mathrm{ab}$ & $193.57 \pm 8.71 b$ & $42.41 \pm 8.74 b$ & $7.32 \pm 3.44 \mathrm{ab}$ & $84.23 \pm 0.18 c$ & $82.55 \pm 0.81 \mathrm{c}$ & $4.31 \pm 0.03 b$ \\
\hline SP2N & $220.83 \pm 23.42 \mathrm{ab}$ & $186.30 \pm 10.82 b$ & $38.61 \pm 6.77 b$ & $8.75 \pm 1.75 b$ & $88.63 \pm 1.20 c$ & $80.51 \pm 1.74 c$ & $4.31 \pm 0.03 b$ \\
\hline $\mathrm{SC} 2 \mathrm{~N}$ & $195.98 \pm 26.82 \mathrm{ab}$ & $181.89 \pm 16.5 b$ & $42.25 \pm 7.81 b$ & $9.17 \pm 1.22 b$ & $89.83 \pm 1.57 c$ & $81.73 \pm 1.39 c$ & $4.33 \pm 0.03 b$ \\
\hline CK & $236.58 \pm 18.93 b$ & $4.11 \pm 0.45 \mathrm{a}$ & $21.48 \pm 2.83 \mathrm{a}$ & $4.13 \pm 0.39 a$ & $5.08 \pm 0.39 a$ & $6.13 \pm 1.35 \mathrm{a}$ & $4.74 \pm 0.01 \mathrm{c}$ \\
\hline SN & $203.19 \pm 4.82 \mathrm{ab}$ & $186.23 \pm 14.51 b$ & $19.32 \pm 3.10 \mathrm{a}$ & $3.82 \pm 0.59 a$ & $64.01 \pm 1.60 \mathrm{~b}$ & $51.08 \pm 2.02 b$ & $4.21 \pm 0.03 a$ \\
\hline
\end{tabular}

DOC: Dissolved organic C, DON: dissolved organic N, MBC: microbial biomass C, MBN: microbial biomass N.

SP1: soil + 1\% biochar made from Pinus massoniana trunk (PB); SC1: soil + 1\% biochar made from Cunninghamia lanceolata trunk (CB); SP2: soil + 2\% PB; SC2: soil + 2\% CB; SP1N: soil + 1\% PB + N; SC1N: soil + 1\% CB + N; SP2N: soil + 2\% PB + N; SC2N: soil + 2\% CB + N; QP2: quartz sand + PB; QC2: quartz sand $+\mathrm{CB}$; CK: soil only; $\mathrm{SN}$ : soil $+\mathrm{N}$.

Table 4. Total amounts of released $\mathrm{CO}_{2}-\mathrm{C}$ during the incubation.

\begin{tabular}{lc}
\hline Treatments & Amounts of $\mathrm{CO}_{2}-\mathrm{C}(\mathrm{mg})$ \\
\hline SP1 & $2.66 \pm 0.13 \mathrm{cde}$ \\
SC1 & $2.94 \pm 0.26 \mathrm{de}$ \\
SP2 & $3.15 \pm 0.31 \mathrm{e}$ \\
SC2 & $3.23 \pm 0.38 \mathrm{e}$ \\
SP1N & $2.14 \pm 0.30 \mathrm{bc}$ \\
SC1N & $2.02 \pm 0.11 \mathrm{bc}$ \\
SP2N & $2.41 \pm 0.17 \mathrm{~cd}$ \\
SC2N & $2.25 \pm 0.36 \mathrm{~cd}$ \\
QP2 & $0.92 \pm 0.05 \mathrm{a}$ \\
QC2 & $0.81 \pm 0.24 \mathrm{a}$ \\
CK & $1.65 \pm 0.20 \mathrm{~b}$ \\
QP2 + CK & $2.57 \pm 0.17 \mathrm{~cd}$ \\
QC2 + CK & $2.45 \pm 0.16 \mathrm{~cd}$ \\
SN & $1.46 \pm 0.07 \mathrm{~b}$ \\
QP2 + SN & $2.38 \pm 0.02 \mathrm{~cd}$ \\
QC2 + SN & $2.27 \pm 0.24 \mathrm{~cd}$
\end{tabular}

$\mathrm{QP} 2+\mathrm{CK}, \mathrm{QC} 2+\mathrm{CK}, \mathrm{QP} 2+\mathrm{SN}$, and $\mathrm{QC} 2+\mathrm{SN}$ represent the sum of $\mathrm{CO}_{2}-\mathrm{C}$ released from the sand-biochar treatments and from the controls (CK or $\mathrm{SN}$ ). SP1: soil $+1 \%$ biochar made from Pinus massoniana trunk (PB); SC1: soil + $1 \%$ biochar made from Cunninghamia lanceolata trunk (CB); SP2: soil $+2 \%$ PB; SC2: soil + 2\% CB; SP1N: soil + 1\% PB + N; SC1N: soil + $1 \% \mathrm{CB}+\mathrm{N}$; SP2N: soil $+2 \%$ PB + N; SC2N: soil $+2 \% \mathrm{CB}+\mathrm{N}$; QP2: quartz sand + PB; QC2: quartz sand $+\mathrm{CB}$; CK: soil only; $\mathrm{SN}$ : soil $+\mathrm{N}$.

(Bruun et al., 2011). Labile C fractions in both PB and $\mathrm{CB}$ is a main source of $\mathrm{C}$ mineralization in the short term (Cheng et al., 2006), as shown by the labile $\mathrm{C}$ fraction contents (Table 1) and released $\mathrm{CO}_{2}-\mathrm{C}$ in QP2 and QC2 (Table 2 and Figure 2), which may incur soil C mineralization (Luo et al., 2011). The increased soil microbial biomass (Table 3) suggests that soil microorganism growth has been promoted by the biochar additions as the labile $\mathrm{C}$ fractions benefit microorganisms (Calvelo Pereira et al., 2011). Thus, both the $\mathrm{C}$ mineralization of abiotic process in the biochars and the microorganism process in the soil, contributes to the $\mathrm{CO}_{2}-\mathrm{C}$ enhancement following the addition of biochar. However, the habitat-availability effects of biochar on soil microorganisms are relatively minor in the short term (Quilliam et al., 2013), which accounts for the non-significant differences in both the released $\mathrm{CO}_{2}$ and microbial biomass between the soil-PB and soil-CB treatments; even though there are notable differences in the surface areas between $\mathrm{PB}$ and CB (Table 1).

\section{Effects of biochar combined with external $\mathbf{N}$ on soil $\mathrm{C}$ mineralization}

Increased levels of $\mathrm{CO}_{2}-\mathrm{C}$ in the soil-biochar-N vs. soil-biochar treatments (Figure 2) and relatively few differences in the total cumulative $\mathrm{CO}_{2}-\mathrm{C}$ values between soil-biochar- $\mathrm{N}$ treatments and $\mathrm{SN}$ (Table 2) suggest that when biochar is added with external $\mathrm{N}$, it cannot facilitate soil $\mathrm{C}$ mineralization in the short term. This conclusion is supported by the non-significant differences $(P>0.05)$ in the total amount of $\mathrm{CO}_{2}-\mathrm{C}$ released in $\mathrm{SP} 2 \mathrm{~N} v s . \mathrm{QP} 2+\mathrm{SN}$ and $\mathrm{SC} 2 \mathrm{~N} v s . \mathrm{QC} 2+$ SN (Table 4), and by the lower levels of potentially available $\mathrm{C}\left(C_{0}\right)$ per unit total $\mathrm{C}$ in soil-biochar-N vs. soil-biochar treatments (Table 2). Decreased soil $\mathrm{pH}$ and few changes in microbial biomass between soil-biochar-N and soil-biochar treatments (Table 3) suggest that the restrictive effects of biochar additions associated with external $\mathrm{N}$ on microorganism activity contribute to the mineralization suppression since soil acidity is critical to soil microbial functionality (Aciego Pietri and Brookes, 2008). Further evidence is provided by the correlation between $\mathrm{pH}$ and the total cumulative $\mathrm{CO}_{2}-\mathrm{C}$ values in the $\mathrm{N}$-present treatments $(r=0.625, P<0.05, n=15)$. The suppression effects observed in this study is different from previous findings in the literature (Gundale and DeLuca, 2007). This may be attributed to the different type of external $\mathrm{N}$ (i.e., glycine in the literature) because biochar additions associated with urea (another external $\mathrm{N}$ ) has also lowered soil $\mathrm{pH}$ after more than $50 \mathrm{~d}$ (Clough et al., 2010). The higher levels of mineral $\mathrm{N}$ and increased $\mathrm{pH}$ in soil-biochar-N treatments $v s$. SN confirm that biochar can retain external added mineral N (Güereña et al., 2013), and suggest that the biochars can amend acidic soils due to the oxygen-containing functional groups (Figure 1) (Xu et al., 2012). Simultaneously, this association can maintain organic $\mathrm{C}$ in the soil in the short term. Thus, the biochars associated with mineral $\mathrm{N}$ fertilizer can amend acidic soils more effectively than the biochars alone. 


\section{Carbon mineralization kinetics according to model fitting}

According to the first-order kinetic model applied in this study, the turnover rate of available $\mathrm{C}$ increases following the addition of biochar but slows when external $\mathrm{N}$ is added simultaneously, as demonstrated by the distribution of $k$ (Zhou et al., 2012), and responds to the decline of $\mathrm{C}$ mineralization in soil-biochar- $\mathrm{N}$ vs. soil-biochar treatments. However, the amount of $\mathrm{C}$ mineralization is minor compared to the total C (Figure 3 and Table 2), suggesting that the biochar additions (whether or not they are associated with external $\mathrm{N}$ ) can improve $\mathrm{C}$ storage in the soil. This is supported by the lower values of the potential labile $\mathrm{C}$ per unit total $\mathrm{C}$ in the soil-biochar-N and soil-biochar treatments compared to the controls (Table 2). This result is similar to previous findings in that the short-term $\mathrm{C}$ loss should no compromise the ability of biochar to store C in soils (Smith et al., 2010; Jones et al., 2011).

\section{CONCLUSIONS}

This study has demonstrated that $\mathrm{C}$ mineralization in the soil can be enhanced by the biochars through stimulating soil microorganisms in the short term, and that this process is not sensitive to simultaneous additions of external N. Carbon storage in the soil is improved after biochar addition (whether or not it is associated with external N). Plantation-waste (e.g., Pinus massoniana and Cunninghamia lanceolata trunks) biochar associated with mineral $\mathrm{N}$ fertilizer can amend degraded soils (e.g., acidic soil). Therefore, double benefits of $\mathrm{C}$ sequestration and soil amendment can be enhanced by adding biochar with $\mathrm{N}$ fertilizer.

The study area is located in the hilly red soil region of southern China, where soils are infertile and drastically mineralized. Based on the findings in this study, chemical fertilizer application to soils could be associated with biochar, through which multi-benefits (e.g., soil amendment, environment protection, C sequestration) could be obtained simultaneously. And thus, additional experiments are recommended using biochar associated with different amendments to determine whether or not the effects of biochar on $\mathrm{C}$ sequestration are more permanent.

\section{ACKNOWLEDGEMENTS}

This work was supported in part by the Ministry of Science and Technology, China (KY-2012-09-05) and the Fundamental Research Funds for the Central Universities (2012XZZX012) with additional support from the University of Western Australia.

\section{LITERATURE CITED}

Aciego Pietri, J.C., and P.C. Brookes. 2008. Relationships between soil $\mathrm{pH}$ and microbial properties in a UK arable soil. Soil Biology and Biochemistry 40:1856-1861.

Anders, E., A. Watzinger, F. Rempt, B. Kitzler, B. Wimmer, F. Zehetner, et al. 2013. Biochar affects the structure rather than the total biomass of microbial communities in temperate soils. Agricultural and Food Science 22:404-423.

ASTM. 2007. ASTM D1762-84 standard test method for chemical analysis of wood charcoal. ASTM International, West Conshohocken, Pennsylvania, USA.

Borchard, N., A. Wolf, V. Laabs, R. Aeckersberg, H.W. Scherer, A. Moeller, et al. 2012. Physical activation of biochar and its meaning for soil fertility and nutrient leaching-a greenhouse experiment. Soil Use and Management 28:177-184.

Brookes, P.C., A. Landman, G. Pruden, and D.S. Jenkinson. 1985. Chloroform fumigation and the release of soil nitrogen: a rapid direct extraction method to measure microbial biomass nitrogen in soil. Soil Biology and Biochemistry 17:837-842.

Bruun, S., S. Clauson-Kaas, L. Bobul'ská, and I.K. Thomsen. 2014. Carbon dioxide emissions from biochar in soil: role of clay, microorganisms and carbonates. European Journal of Soil Science 65:52-59.

Bruun, E.W., H. Hauggaard-Nielsen, N. Ibrahim, H. Egsgaard, P. Ambus, P.A. Jensen, et al. 2011. Influence of fast pyrolysis temperature on biochar labile fraction and short-term carbon loss in a loamy soil. Biomass \& Bioenergy 35:1182-1189.

Calvelo Pereira, R., J. Kaal, M. Camps Arbestain, R. Pardo Lorenzo, W. Aitkenhead, M. Hedley, et al. 2011. Contribution to characterisation of biochar to estimate the labile fraction of carbon. Organic Geochemistry 42:1331-1342.

Chan, K.Y., L. Van Zwieten, I. Meszaros, A. Downie, and S. Joseph. 2008. Using poultry litter biochars as soil amendments. Soil Research 46:437-444.

Cheng, C.-H., J. Lehmann, J.E. Thies, S.D. Burton, and M.H. Engelhard. 2006. Oxidation of black carbon by biotic and abiotic processes. Organic Geochemistry 37:1477-1488.

Clough, T.J., J.E. Bertram, J.L. Ray, L.M. Condron, M. O'Callaghan, R.R. Sherlock, et al. 2010. Unweathered wood biochar impact on nitrous oxide emissions from a bovine-urine-amended pasture soil. Soil Science Society of America Journal 74:852-860.

Gaskin, J.W., C. Steiner, K. Harris, K.C. Das, and B. Bibens. 2008. Effect of low-temperature pyrolysis conditions on biochar for agricultural use. Transactions of the American Society of Agricultural and Biological Engineers 51:2061-2069.

Gomez, J.D., K. Denef, C.E. Stewart, J. Zheng, and M.F. Cotrufo. 2014. Biochar addition rate influences soil microbial abundance and activity in temperate soils. European Journal of Soil Science 65:28-39.

Güereña, D., J. Lehmann, K. Hanley, A. Enders, C. Hyland, and S. Riha. 2013. Nitrogen dynamics following field application of biochar in a temperate North American maize-based production system. Plant and Soil 365:239-254.

Gundale, M.J., and T.H. DeLuca. 2007. Charcoal effects on soil solution chemistry and growth of Koeleria macrantha in the ponderosa pine/Douglas-fir ecosystem. Biology and Fertility of Soils 43:303-311.

Jones, D.L., D.V. Murphy, M. Khalid, W. Ahmad, G. Edwards-Jones, and T.H. DeLuca. 2011. Short-term biochar-induced increase in soil $\mathrm{CO}_{2}$ release is both biotically and abiotically mediated. Soil Biology and Biochemistry 43:1723-1731.

Jones, D.L., J. Rousk, G. Edwards-Jones, T.H. DeLuca, and D.V. Murphy. 2012. Biochar-mediated changes in soil quality and plant growth in a three year field trial. Soil Biology and Biochemistry 45:113-124.

Kolb, S.E., K.J. Fermanich, and M.E. Dornbush. 2009. Effect of charcoal quantity on microbial biomass and activity in temperate soils. Soil Science Society of America Journal 73:1173-1181. 
Kuzyakov, Y., I. Subbotina, H. Chen, I. Bogomolova, and X. Xu. 2009. Black carbon decomposition and incorporation into soil microbial biomass estimated by ${ }^{14} \mathrm{C}$ labeling. Soil Biology and Biochemistry 41:210-219.

Lefèvre, R., P. Barré, F.E. Moyano, B.T. Christensen, G. Bardoux, T. Eglin, et al. 2014. Higher temperature sensitivity for stable than for labile soil organic carbon - Evidence from incubations of long-term bare fallow soils. Global Change Biology 20:633-640.

Luo, Y., M. Durenkamp, M. De Nobili, Q. Lin, and P.C. Brookes. 2011. Short term soil priming effects and the mineralisation of biochar following its incorporation to soils of different $\mathrm{pH}$. Soil Biology and Biochemistry 43:2304-2314.

Mulcahy, D.N., D.L. Mulcahy, and D. Dietz. 2013. Biochar soil amendment increases tomato seedling resistance to drought in sandy soils. Journal of Arid Environments 88:222-225.

Quilliam, R.S., H.C. Glanville, S.C. Wade, and D.L. Jones. 2013. Life in the 'charosphere' - Does biochar in agricultural soil provide a significant habitat for microorganisms? Soil Biology and Biochemistry 65:287-293.

Sarkhot, D.V., A.A. Berhe, and T.A. Ghezzehei. 2012. Impact of biochar enriched with dairy manure effluent on carbon and nitrogen dynamics. Journal of Environmental Quality 41:1107-1114.

Smith, J.L., H.P. Collins, and V.L. Bailey. 2010. The effect of young biochar on soil respiration. Soil Biology and Biochemistry 42:2345-2347.

Spokas, K.A. 2013. Impact of biochar field aging on laboratory greenhouse gas production potentials. Global Change Biology Bioenergy 5:165-176.

Vance, E.D., P.C. Brookes, and D.S. Jenkinson. 1987. An extraction method for measuring soil microbial biomass C. Soil Biology and Biochemistry 19:703-707.
Verheijen, F.G.A., E.R. Graber, N. Ameloot, A.C. Bastos, S. Sohi, and H. Knicker. 2014. Biochars in soils: new insights and emerging research needs. European Journal of Soil Science 65:22-27.

Wolf, M., E. Lehndorff, G.L.B. Wiesenberg, M. Stockhausen, L. Schwark, and W. Amelung. 2013. Towards reconstruction of past fire regimes from geochemical analysis of charcoal. Organic Geochemistry 55:11-21.

Xu, R-k., A-z. Zhao, J-h. Yuan, and J. Jiang. 2012. pH buffering capacity of acid soils from tropical and subtropical regions of China as influenced by incorporation of crop straw biochars. Journal of Soils and Sediments 12:494-502.

Ye, L.L., C. Wang, H. Zhou, and X. Peng. 2012. Effects of rice strawderived biochar addition on soil structure stability of an Ultisol. Soils 44:62-66. (In Chinese).

Yu, X., L. Pan, G. Ying, and R.S. Kookana. 2010. Enhanced and irreversible sorption of pesticide pyrimethanil by soil amended with biochars. Journal of Environmental Sciences 22: 615-620.

Yuan, J-H., R-K. Xu, W. Qian, and R-H. Wang. 2011. Comparison of the ameliorating effects on an acidic ultisol between four crop straws and their biochars. Journal of Soils and Sediments 11:741-750.

Zhang, J., F. Lü, C. Luo, L. Shao, and P. He. 2014. Humification characterization of biochar and its potential as a composting amendment. Journal of Environmental Sciences 26:390-397.

Zhou, X., C. Chen, S. Lu, Y. Rui, H. Wu, and Z. Xu. 2012. The short-term cover crops increase soil labile organic carbon in southeastern Australia. Biology and Fertility of Soils 48:239-244. 